\title{
Combined Antimicrobial Effect of Bio-Waste Olive Leaf Extract and Remote Cold Atmospheric Plasma Effluent
}

\author{
Jose Gustavo De la Ossa ${ }^{1,2,3}$, Hani El Kadri ${ }^{2}$, Jorge Gutierrez-Merino ${ }^{4}$, Thomas Wantock ${ }^{5}$, Thomas Harle ${ }^{5}$, \\ Maurizia Seggiani ${ }^{6}$, Serena Danti ${ }^{6, *} * \mathbb{D}$, Rossella Di Stefano ${ }^{3,7}$ and Eirini Velliou ${ }^{2,8, *}$
}

1 Doctoral School in Life Sciences, University of Siena, 53100 Siena, Italy; josegustavo.delao@student.unisi.it

2 Bioprocess and Biochemical Engineering Group (BioProChem), Department of Chemical and Process Engineering, University of Surrey, Guildford GU2 7XH, UK; h.elkadri@surrey.ac.uk

3 Cardiovascular Research Laboratory, Department of Surgical, Medical and Molecular Pathology and Critical Care Medicine, University of Pisa, 56100 Pisa, Italy; rossella.distefano@unipi.it

4 School of Biosciences and Medicine, University of Surrey, Guildford GU2 7XH, UK; j.gutierrez@surrey.ac.uk

5 Fourth State Medicine Ltd., Longfield, Fernhurst, Haslemere GU27 3HA, UK; t.wantock@surrey.ac.uk (T.W.); t.harle@fourthstatemedicine.co.uk (T.H.)

6 Department of Civil and Industrial Engineering, University of Pisa, Largo L. Lazzarino 2, 56122 Pisa, Italy; maurizia.seggiani@unipi.it

7 Interdepartmental Research Center "Nutraceuticals and Food for Health", University of Pisa, 56100 Pisa, Italy

8 Centre for 3D Models of Health and Disease, Division of Surgery and Interventional Science,

University College London, London W1W 7TY, UK

* Correspondence: serena.danti@unipi.it (S.D.); e.velliou@surrey.ac.uk (E.V.); Tel.: +39-050-2217874 (S.D.); +44-01483-686577 (E.V.)

check for

updates

Citation: De la Ossa, J.G.; El Kadri, H.; Gutierrez-Merino, J.; Wantock, T.; Harle, T.; Seggiani, M.; Danti, S.; Di Stefano, R.; Velliou, E. Combined Antimicrobial Effect of Bio-Waste Olive Leaf Extract and Remote Cold Atmospheric Plasma Effluent. Molecules 2021, 26, 1890. https:// doi.org/10.3390/molecules26071890

Academic Editor: Maria Atanassova

Received: 18 January 2021

Accepted: 22 March 2021

Published: 26 March 2021

Publisher's Note: MDPI stays neutral with regard to jurisdictional claims in published maps and institutional affiliations.

Copyright: (c) 2021 by the authors Licensee MDPI, Basel, Switzerland. This article is an open access article distributed under the terms and conditions of the Creative Commons Attribution (CC BY) license (https:// creativecommons.org/licenses/by/ $4.0 /)$.
Abstract: A novel strategy involving Olive Leaf Extract (OLE) and Cold Atmospheric Plasma (CAP) was developed as a green antimicrobial treatment. Specifically, we reported a preliminary investigation on the combined use of OLE + CAP against three pathogens, chosen to represent medical and food industries (i.e., E. coli, S. aureus and L. innocua). The results indicated that a concentration of $100 \mathrm{mg} / \mathrm{mL}$ (total polyphenols) in OLE can exert an antimicrobial activity, but still insufficient for a total bacterial inactivation. By using plain OLE, we significantly reduced the growth of Gram positive S. aureus and L. innocua, but not Gram-negative E. coli. Instead, we demonstrated a remarkable decontamination effect of OLE + CAP in E. coli, S. aureus and L. innocua samples after $6 \mathrm{~h}$. This effect was optimally maintained up to $24 \mathrm{~h}$ in S. aureus strain. E. coli and L. innocua grew again in $24 \mathrm{~h}$. In the latter strain, OLE alone was most effective to significantly reduce bacterial growth. By further adjusting the parameters of OLE + CAP technology, e.g., OLE amount and CAP exposure, it could be possible to prolong the initial powerful decontamination over a longer time. Since OLE derives from a bio-waste and CAP is a non-thermal technology based on ionized air, we propose OLE + CAP as a potential green platform for bacterial decontamination. As a combination, OLE and CAP can lead to better antimicrobial activity than individually and may replace or complement conventional thermal procedures in food and biomedical industries.

Keywords: polyphenols; olive tree; green technology; antibacterial; food contamination; S. aureus; E. coli; L. innocua

\section{Introduction}

There is a growing interest in sustainable industrial routes, with special emphasis in the food and biomedical sectors, for the manufacture of safe yet sustainable packaging for edible products as well as surgical devices [1,2]. Consequently, the attention towards less impactful processing technologies capable of replacing conventional decontamination methods is increasing. To this end, natural antimicrobial compounds, including vegetable bioactive molecules, offer an emerging strategy to control microbial contamination. Indeed, some molecules and plant-derivatives demonstrate good antimicrobial activity against 
pathogenic bacteria found in packaging or processing phases in the food industry [1], as well as in biomedical devices, such as surgical tools and supporting equipment, the latter being very important in healthcare, since inaccurate sterilization is responsible for at least $1.5 \%-7.2 \%$ of post-operative complications [2]. The antibacterial properties of plants have been widely investigated [3]. In fact, a great variety of plant species containing components which exhibit antimicrobial activity against a wide range of Gram-positive and Gram-negative bacteria has been reported, including Hibiscus, Rosmarinus officinalis, Thymus vulgaris, Malva sylvestris and Allium sativum, among others [4-14]. Plant antimicrobials are more attractive than the synthetic food preservatives, as they are generally recognized as safe and capable of benefiting human health, including essential oils [15]. Olive Leaf Extract (OLE), an agricultural by-product obtained during the harvesting or pruning process of olive fruits, can be considered as a plant derivative entitled with both antimicrobial and antioxidant activities [16]. The leaves of olive trees (i.e., Olea europaea, Oleaceae) together with small and large branches produced from the cultivation and harvesting of olives represent waste biomasses, usually burned by farmers with consequent production of greenhouse gases [17]. As such, their conversion into higher-value products can represent a sustainable and eco-friendly alternative to their current disposal. To obtain OLE from olive oil leaves, a water-based extraction method can be applied in place of organic solvent solutions [18]. In fact, widely used OLE extraction procedures based on ethanol and methanol aqueous solutions have shown shortcomings such as low extraction efficiency, prolonged extraction times and high energy consumption for heating [19]. OLE is used in traditional medicine as a dietary supplement and an over-the-counter drug for a variety of beneficial effects on human health, such as lowering blood pressure and supporting the cardiovascular and immune systems [20]. OLE and the other parts of the olive tree contain considerable amounts of polyphenols [18]. Specifically, OLE contains oleuropein, the main phenolic compound found in unprocessed olive fruits and leaves, up to $140 \mathrm{mg} / \mathrm{g}$ and $60-90 \mathrm{mg} / \mathrm{g}$, respectively [21]. Oleuropein is a glycosylated seco-iridoid glucoside composed of elenolic acid and hydroxy-tyrosol; it has an oleosidic skeleton that is common within the seco-iridoid glucosides of Oleaceae, mainly in its aglycone form, which makes the sugar moiety insoluble in oil [22].According to some studies, OLE exerts antimicrobial effects due to its high phenolic content $[16,23,24]$. They report the growth inhibition in some bacteria species, reported in Table 1 . However, these findings are contradictory and may depend on the concentration and/or the bacteria used. For example, Sudjana et al. showed that OLE had appreciable antimicrobial activity only against C. jejuni, H. pylori and Staphylococcus spp., but poor effect against B. subtilis, Candida spp., E. coli, K. pneumoniae, $P$. aeruginosa and S. marcescens [25]. Djanane et al. showed that 5\% OLE was more efficient as compared to 1\% OLE against the pathogens Salmonella and E. coli O157:H7 in Halal meat [26]. Albertos et al. reported that edible films with OLE at 5.6\% $(w / w)$ reduced $L$. monocytogenes growth on smoked salmon [27]. Furthermore, in a study by Pereira et al., OLE was screened for its antimicrobial activity against B. cereus, B. subtilis, S. aureus, E. coli, $P$. aeruginosa, K. pneumoniae bacteria and against the fungi $C$. albicans and $C$. neoformans, showing B. cereus and C. albicans to be the most sensitive to OLE [28]. Therefore, the use of OLE as antimicrobial treatment is still a matter of debate due to the contradictory results of the insufficient number of systematic studies conducted so far $[29,30]$. 
Table 1. Bacterial growth inhibition studies with olive leaf extract (OLE) treatment on bacteria strains.

\begin{tabular}{|c|c|c|c|c|}
\hline Bacterial Species & Olive Variety and Origin & OLE Extraction Method & OLE Concentration & Reference \\
\hline K. pneumoniae & $\begin{array}{c}\text { Olea europaea (Turkey, west } \\
\text { Anatolian) }\end{array}$ & Aqueous & $30 \mu \mathrm{L} \mathrm{OLE} ; 15 \%(w / v)$ & {$[22,30]$} \\
\hline S. aureus & Olea europaea (Portugal) & Aqueous & $5 \mathrm{mg} / \mathrm{mL}$ & {$[28,29]$} \\
\hline B. cereus & Olea europaea (Portugal) & Aqueous & $5 \mathrm{mg} / \mathrm{mL}$ & [28] \\
\hline B. subtilis & Olea europaea & Ethanol & $27.2 \pm 0.99 \mathrm{mg} / \mathrm{g}$ & [28] \\
\hline P. aeruginosa & Olea europaea (Portugal) & Aqueous & $5 \mathrm{mg} / \mathrm{mL}$ & [28] \\
\hline C. jejuni & Olea europaea (Australia) & n.a. & n.a. & [27] \\
\hline H. pylori & Olea europaea (Australia) & n.a. & n.a. & [27] \\
\hline E. coli & Olea europaea (Several countries) & Water, ethanol. & Variable & {$[28,30,31]$} \\
\hline S. enterica & $\begin{array}{c}\text { Olea europaea subsp. europaea var. } \\
\text { Sylvestris (Algeria) }\end{array}$ & Methanol/water & $198.7 \pm 3.6 \mathrm{mg} \mathrm{GAE} / \mathrm{g}$ & {$[27,28,30]$} \\
\hline L. monocytogenes & Commercial extract (USA) & Water/ethanol & $62.5 \mathrm{mg} / \mathrm{mL}$ & {$[27,30]$} \\
\hline
\end{tabular}

Another emerging non-thermal technology with potential applications in several different industries, including safe and sustainable food production, is Cold Atmospheric Plasma (CAP). Plasma is commonly referred to as the fourth state of matter, namely, an ionized state of gas which exhibits unique properties. The plasma state is pervasive, being found in diverse entities (e.g., stars, interstellar space, lighting technology). Cold plasma $(\mathrm{CP})$ is commonly obtained by application of a strong electromagnetic field to a neutral gas that induces ionization. CP is composed of ions, electrons, free radicals, excited atoms/molecules and photons of various wavelengths. CAP treatment in the presence of air generates several reactive short and long-lived species including reactive oxygen species (ROS) and reactive nitrogen species (RNS), which have been shown to play a dominant role in antibacterial and biological activity [31-33]. CAP, due its non-thermal nature, is a potential alternative to conventional methods such as the use of chlorine and thermal processes (i.e., drying, chilling, freezing and pasteurization) to improve microbiological safety in food packaging [34].

In the biomedical field, this technique can be applied in surface disinfection, sterilization of surgical instruments and decontamination of devices [2]. Moreover, plasma devices, such as indirect argon plasma (e.g., MicroPlaSter alpha and beta), have been applied in a clinical trial in patients with chronic infected wounds [2]. Some studies reported that CAP exhibited excellent antibacterial efficacy against target food pathogens, their spores and biofilms [35]. In addition, new information has been elucidated explaining the effective application of $\mathrm{CP}$ in functional packaging, for elimination of toxins and degradation of pesticides [36]. Plasma has also been investigated as a pre-treatment step to activate or modify material surfaces, since it can improve the efficiency of post-grafting or the incorporation of antimicrobial components onto the surface [37]. Chang et al. used plasma pre-treatment to promote the grafting of chitosan on polyester fabrics to obtain antibacterial activity against $B$. subtilis and S. aureus [37]. In this study, fabrics were previously pre-treated by an argon/oxygen $\left(\mathrm{Ar} / \mathrm{O}_{2}\right)$ dielectric barrier discharge (DBD) plasma for surface activation, subsequently exposed to the atmosphere for further oxidization and, finally, immersed in a chitosan solution for chitosan grafting. Other natural compounds, such as nisin peptides, thymol and herbs, have also been grafted onto plasma pre-treated polymer surfaces to obtain an antibacterial material [38-40]. Different types of plasma pre-treatments, namely $\mathrm{N}_{2}$ and $\mathrm{Ar} / \mathrm{O}_{2}$ plasma modifications, and plasma-induced grafting of acrylic acid have been used to incorporate nisin peptides onto the surface of low density poly-ethylene films [40]. Other interesting developments using whey protein formulations as coating strategies on polyethylene terephthalate films, pre-treated by corona discharge of $\mathrm{CAP}$, resulted in excellent barrier properties, making the packaging efficacy comparable to the ethylene vinyl alcohol copolymers barrier layer, conventionally used in food packaging composites [41]. Similarly, in another study, the application of plasticized corn-zein coating on corona-discharge-treated polypropylene films for the flexible packaging industry showed more than three orders of reduction in oxygen permeability [42]. Hence, although the 
antimicrobial properties of plain OLE is still debated, OLE can be used in combination with CAP treatment (OLE + CAP) to empower antimicrobial activity against bacteria present in the food and biomedical industries. In this way, it is expected to replace or complement conventional sterilization and decontamination processes that use high energy with those of lower environmental impact $[43,44]$. Overall, both OLE and CAP are sustainable technologies for bacterial decontamination purposes; however, singularly, their action is not as strong and efficient as heat sterilization. The OLE + CAP combination represents a novel approach that involves the bioactive molecules of OLE and ROS/RNS generated in situ by CAP. In this study, the antibacterial activity of OLE, CAP and OLE + CAP against common bacterial species affecting both food and medical devices was preliminarily investigated to determine potential synergistic effects between the two approaches. Having a combined green technology for bacterial decontamination would allow more sustainable and better management of human health.

\section{Results}

\subsection{Effect of OLE on Bacterial Strains}

The OLE used was extracted from Olea europaea var. Olivastra seggianese in Tuscan cultivar [45]. The antibacterial activity was evaluated in vitro against gram-negative E. coli and gram-positive S. aureus and L. innocua strains. Each resuspended E. coli, S. aureus and L. innocua sample was separately treated with OLE at $100 \mathrm{mg} / \mathrm{mL}$ total polyphenols (TPs), as this concentration is within the range of efficiency [46]. The effect of OLE on the different bacteria is illustrated in Figure 1. OLE composition is given in Table 2.

a

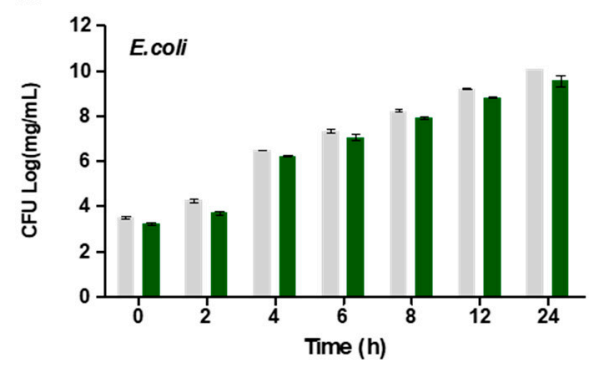

b

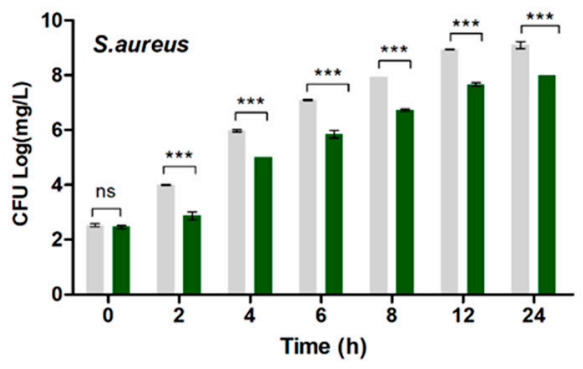

c

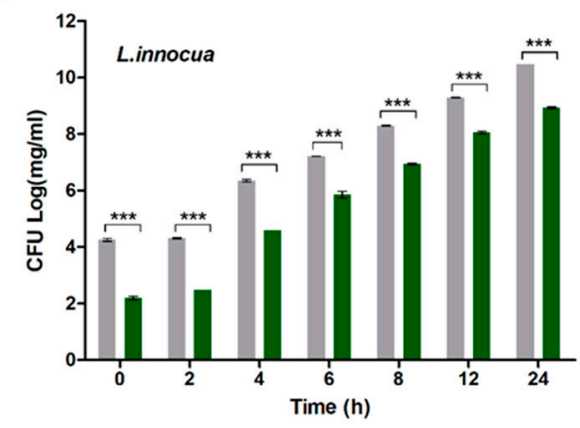

$\square$ Control

$\square$ OLE

Figure 1. Bar graphs showing the effect of OLE administration at $100 \mathrm{mg} / \mathrm{mL}$ total polyphenols (TPs) on the growth of different bacterial strains: (a) E. coli, (b) S. aureus, (c) L. innocua, up to $24 \mathrm{~h}$. The values are reported as mean \pm standard error of the mean (SEM) $(n=3)$, significance at $p<0.05$ by One-way ANOVA and Tukey's HSD post hoc test; ${ }^{* * *} p<0.0001$, n.s. not significant.

For E. coli, OLE did not exhibit any significant antimicrobial effect (Figure 1a). Conversely, in S. aureus and L. innocua statistically significant antimicrobial effects were observed over time (Figure 1b,c). In particular, for L. innocua OLE showed a reduction in the number of colonies even if inactivation was not reached (Figure 1c). 
Table 2. Concentration of the main polyphenols in OLE.

\begin{tabular}{cc}
\hline OLE Composition & Concentration $(\mathbf{m g} / \mathbf{g}$ OLE) \\
\hline Oleuropein & $32.64 \pm 3.06$ \\
Luteolin-7-O-glucoside & $6.97 \pm 0.24$ \\
Rutin & $3.37 \pm 0.33$ \\
Apigenin-7-O-glucoside & $1.97 \pm 0.17$ \\
Hydroxy-tyrosol & $0.85 \pm 0.08$ \\
Caffeic acid & $0.18 \pm 0.02$ \\
\hline
\end{tabular}

\subsection{Effect of OLE + CAP on Bacterial Strains}

The potential synergistic effect of OLE and CAP was evaluated at two relevant time points, $6 \mathrm{~h}$ and $24 \mathrm{~h}$ after application of OLE, CAP or OLE + CAP, using previously published methods [47-49]. The comparison of results obtained after $6 \mathrm{~h}$ and $24 \mathrm{~h}$ using the single treatment and their combination is reported in Figures 2-4. Using the combined OLE + CAP treatment, E. coli had significant inhibition at $6 \mathrm{~h}$, while at $24 \mathrm{~h}$ the bacteria reproduced, but still with a significant reduction with respect to the control and individual treatments (Figure 2). The most remarkable effect was obtained against S. aureus (Figure 3).

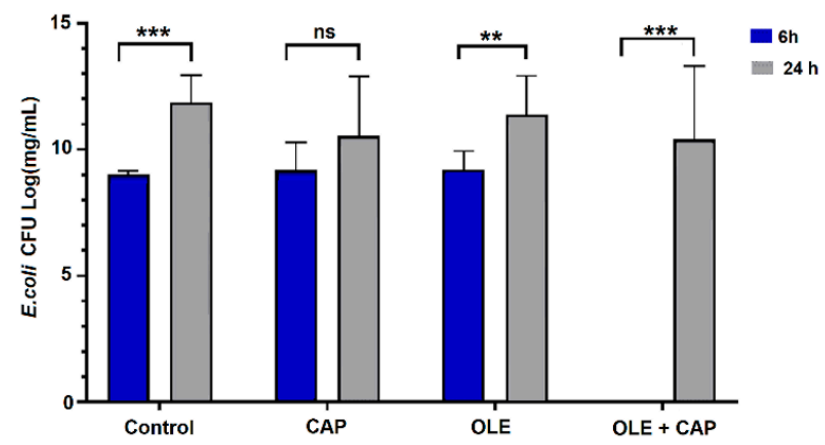

Figure 2. The effects of Cold Atmospheric Plasma (CAP) (1 min exposure time) and/or OLE on $E$. coli. The values are reported as mean \pm standard error of the mean (SEM) $(n=3)$, significance at $p<0.05$ by One-way ANOVA and Tukey's HSD post hoc test; ${ }^{* *} p<0.001,{ }^{* * *} p<0.0001$, n.s. not significant.

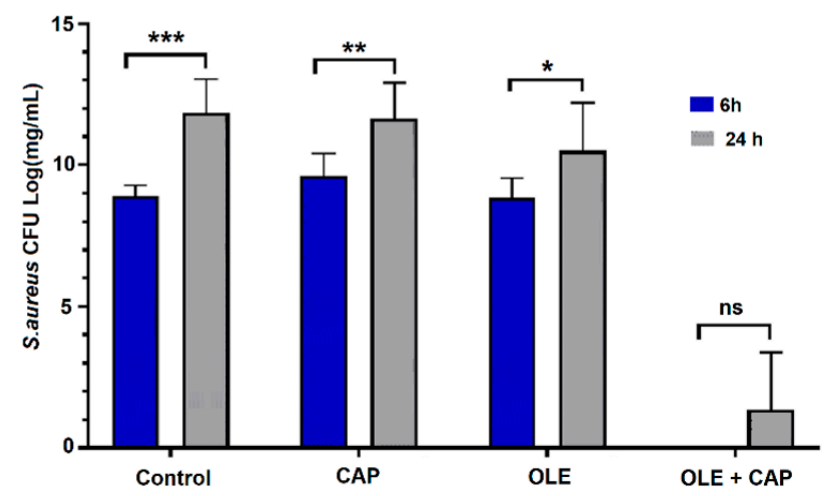

Figure 3. The effects of CAP (1 min exposure time) and/or OLE on S. aureus. The values are reported as mean \pm standard error of the mean (SEM) $(n=3)$, significance at $p<0.05$ by One-way ANOVA and Tukey's HSD post hoc test; ${ }^{*} p<0.01,{ }^{* *} p<0.001,{ }^{* * *} p<0.0001$, n.s. not significant.

S. aureus samples subjected to OLE + CAP treatment significantly decreased after $6 \mathrm{~h}$ and $24 \mathrm{~h}$ compared to control and single treatments. The effectiveness of the combined treatment was confirmed by a very low replication of residual bacteria at $24 \mathrm{~h}$.

The case of L. innocua was more complex. After a high eradication, at $6 \mathrm{~h}$ the bacteria started reproducing and grew up to control levels (Figure 4). 


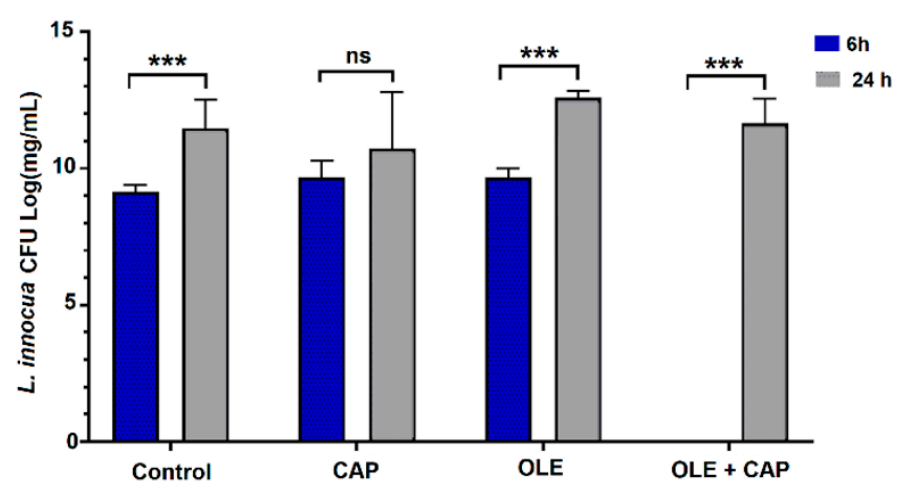

Figure 4. The effects of CAP ( 1 min exposure time) and/or OLE on L. innocua. The values are reported as mean \pm standard error of the mean (SEM) $(n=3)$, significance at $p<0.05$ by One-way ANOVA and Tukey's HSD post hoc test; ${ }^{* * *} p<0.0001$, n.s. not significant.

For this strain, the plain OLE was capable of controlling bacterial growth over time. In L. innocua, bacterial decontamination was observed after $6 \mathrm{~h}$, but the effect was recovered after $24 \mathrm{~h}$, reaching $\sim 7 \cdot \log$ [CFU]. Interestingly, and in accordance with the results reported in Figure 1, OLE alone demonstrated improved effectiveness in containing L. innocua growth.

Overall, the combined treatment (OLE + CAP) showed a synergistic antimicrobial effect against E. coli, S. aureus and L. innocua at $6 \mathrm{~h}$. However, the remaining bacteria in small numbers were able to grow over longer time. The combined OLE + CAP treatment allowed a remarkable bacterial inactivation in terms of colony forming units (CFUs) during the exponential phase $(6 \mathrm{~h})$ for all the strains. In the stationary phase $(24 \mathrm{~h})$, the OLE + CAP treatment was sufficiently effective on $E$. coli, which grew by reaching $\sim 7 \cdot \log [\mathrm{CFU}]$ and was still remarkably effective on $S$. aureus, which grew up to $\sim 3 \cdot \log [\mathrm{CFU}]$, thus confirming the overall synergistic effect of OLE + CAP treatment. Differently, the individual treatments did not demonstrate relevant decontamination activity under our experimental conditions.

\section{Discussion}

The search for novel technologies for bacterial decontamination is a topic of intense research, which encompasses the use of chemical, thermal, radiation and combined treatments. A number of sectors can benefit from safe and green methods, such as bactericidal agents, in particular the food and health industries [1-3]. In time, microbes have started to become resistant to many decontamination technologies used on a large scale, thus leading to the need for newer and more powerful antibacterial agents. On the other hand, health and environmental factors are driving the industry towards less aggressive and better sustainable methods to treat their products [17-19,34]. However, low energy approaches are often less effective than their conventional counterparts. As several plants are known to possess antimicrobial properties, new research is also focusing on analyzing and using plant extracts with antibacterial purposes along with combined treatments, for application on an industrial scale $[15,40]$. The research on this topic is still fragmented, incomplete and controversial, due to the fact that biological derivatives, including OLE, greatly vary in their outcomes $[29,30]$. As such, better detailed and more systematic investigations are necessary to combine plant derivatives with other technologies to enhance antimicrobic efficacy.

We reported a preliminary investigation on the combined use of OLE + CAP against three pathogens, chosen to represent medical and food industries (i.e., E. coli, S. aureus and L. innocua). Since OLE derives from a bio-waste and CAP is a non-thermal technology based on ionized air, we propose OLE + CAP as a novel green approach potentially useful for bacterial decontamination.

It important to consider that OLE has a high variability in the concentration of bioactive compounds, as a consequence of various factors, such as the raw material and the 
extraction process, among others [50]. Moreover, the final composition of the OLE has great importance for its antimicrobial efficacy. Furthermore, broad-spectrum polyphenols have been found in OLE at small concentrations (Table 2), which can probably exert an antimicrobial effect together with the most abundant compound, oleuropein. In our study based on the surface spread method, the bacterial inactivation of plain OLE was evident $(p<0.0001)$ in S. aureus and L. innocua at all the time points up to $24 \mathrm{~h}$, while E. coli did not show a considerable susceptibility to OLE. As a gram-negative bacterium, E. coli is in fact more resistant to conventional methods regarding its eradication [27]. The obtained results indicated that the presence of several phenolic compounds in $100 \mathrm{mg} / \mathrm{mL}$ TPs can exert an antimicrobial activity, but still insufficient to obtain a total or significant bacterial inactivation. It is reported that the polyphenols in OLE, or possibly the synergistic effects among them [16], may be responsible for OLE antimicrobial activity by inducing membrane permeability in bacteria, further inhibition of biochemical pathways and, finally, disintegration of the outer membrane leading to bacterial cell death [51].

The CAP effluent works at room temperature (RT) and atmospheric pressure, which eliminates the need for expensive noble gases, making it economically feasible on an industrial scale. CAP application leads to chemical species, such as ROS/RNS, which in combination with the polyphenolic compounds of OLE, mainly oleuropein, are supposed to inactivate the microorganisms. Recent investigations have shown that CAP efficacy is directly correlated to bacterial cell wall thickness in several species [52,53]. Gram-negative species, such as $P$. aeruginosa, were almost completely eradicated due to their thin cell membrane ( $2.4 \mathrm{~nm}$ cell wall), while Gram-positive species, such as B. subtilis, displayed the highest resistance to CAP, possessing thicker membranes (e.g., $55.4 \mathrm{~nm}$ cell wall). E. coli have a thinner outer membrane compared to the Gram-positive $S$. aureus and $L$. innocua. However, no clear trend is apparent from this and other studies, since complex interactions with the system, process, surface or medium may also impact on CAP efficacy in combination with cell type.

Another significant role in the mechanical disruption of the bacterial cell membrane is the effect of charged particles that could accumulate on the surface and cause electrostatic stress [53]. The reactive species produced in plasma react with the protein amino-acids and cause further structural changes in proteins, finally destroying the quiescent cells [54]. It is hypothesized that such morphological changes overcome the tensile strength of the cell membrane [55]. In fact, S. aureus demonstrated a size reduction of colonies (results not shown). Cell membrane perforation induced by etching enhances the diffusion of secondary reactive species that might be formed in the plasma discharge inside the cell [31]. CP, due to its complex composition and multiple different reactive components, is expected to play a role, independently or synergistically, in the inactivation of microbial targets. Generally, the efficacy of $\mathrm{CP}$ depends on the device design and system operating parameters, such as gas composition, flow rate, moisture, temperature, voltage, and frequency $[31,50,56]$. In addition, the ozone $\mathrm{O}_{3}$, present in CAP effluent could break structural bonds in the peptidoglycan component of the cell wall, such as $\mathrm{C}-\mathrm{O}, \mathrm{C}-\mathrm{N}$ bonds, leading to cell wall destruction and, consequently, cell death [56,57].

On the basis of the results obtained, it can be deduced that CAP, containing ROS/RNS [58], combined with the action of the OLE polyphenols, exerts an enhanced antimicrobial activity by efficient damage and disruption of the bacterial membrane [52,53]. In fact, in combination with OLE, a better inactivation was also obtained with S. aureus, a Grampositive bacterium, probably due to ROS-enhanced intracellular damage [53]. Efficacy of the combined effect of CAP and nisin against L. innocua, grown planktonically or as surface colonies in a food model, has recently been reported as another application for bacteria eradication [59], which is suggestive of a potentiated effect of CAP in combination with selected biomolecules. In fact, in our findings, OLE alone demonstrated improved effectiveness in containing L. innocua growth with respect to OLE + CAP, in which, after a first significant decrease, the bacteria grew again to control level. Especially in this case, 
higher time exposure to CAP or more concentrated OLE could be needed to show a more prolonged effect of bacterial eradication.

All in all, we demonstrated the remarkable effect of OLE + CAP in sample decontamination by E. coli, S. aureus and L. innocua after $6 \mathrm{~h}$. This effect was best maintained up to $24 \mathrm{~h}$ using the S. aureus strain. On the other hand, E. coli and L. innocua grew again after $24 \mathrm{~h}$. In the latter case, OLE alone was most effective by significantly reducing bacterial growth. As the most innovative approaches also consider developing material surfaces with intrinsic antimicrobial properties, e.g., by virtue of nanostructures inhibiting bacterial growth and biofilm formation [60,61], the addition of OLE to those surfaces followed by CAP effluent application could provide a robust antimicrobial strategy. As a combination, OLE and CAP can lead to better antimicrobial activity than individually and may replace or complement conventional thermal procedures in the food and biomedical industries. However, a multifactorial study that takes into account the type of bacteria, time and mode of exposure to CAP, content and type of polyphenols of OLE and overall cost-effectiveness, safety and sustainability is needed to optimize the process for industrial use. For enhanced safety, innovative intelligent labels could be applied to the OLE + CAP packaging to properly monitor the sterilization process as well as the storage conditions [62].

The availability of effective and low cost green technologies to disinfect edible and medical products would greatly impact the management of food- and healthcare-associated infections, overall estimated to affect 30 million people annually in Europe.

\section{Materials and Methods}

\subsection{OLE Extraction and Characterization}

OLE was extracted from Olea europaea var. Olivastra seggianese cultivar. The collection of the leaves from which OLE was extracted was performed at CNR-IVALSA, Follonica (GR), Italy. TP content was determined according to the Folin-Ciocalteu method using gallic acid as the standard equivalent ( $\mu \mathrm{g} \mathrm{GAE} / \mathrm{mg}$ ), purchased from Merk (Darmstadt, Germany) [45]. A high-performance liquid chromatography analysis (HPLC) was carried out to identify and quantify the major phenolic compounds of the obtained OLE.

\subsection{CAP Technology}

A dielectric barrier discharge reactor was used for CAP inactivation provided by Fourth State Medicine Ltd. To generate CP, the instrument was set up at a flow rate of $5 \mathrm{~L} / \mathrm{min}$ air for $1 \mathrm{~min}$. The samples were treated at RT (approx. $20^{\circ} \mathrm{C}$ ). The plasma power supply was set at $8 \mathrm{kV}$ voltage and $20 \mathrm{kHz}$ AC frequency.

\subsection{In Vitro Tests}

Inoculum was prepared from stock cultures of E. coli (ATCC 47076), S. aureus (ATCC 25923) and L. innocua (ATCC 33090), previously stored at $-80{ }^{\circ} \mathrm{C}$ in Tryptic Soy Broth (TSB, Oxoid Ltd., UK), supplemented with 15\% v/v glycerol (Merk, Darmstadt, Germany). More specifically, a loopful of thawed stock culture was inoculated in $15 \mathrm{~mL}$ TSB for $24 \mathrm{~h}$ at $37^{\circ} \mathrm{C}$. Subsequently, $20 \mu \mathrm{L}$ was transferred to fresh $20 \mathrm{~mL}$ TSB and cultured at $37^{\circ} \mathrm{C}$ for either $6 \mathrm{~h}$ or $24 \mathrm{~h}$ to obtain bacterial cells in the exponential or stationary phase, respectively, following a procedure reported in previous studies [48-50]. Thereafter, $1 \mathrm{~mL}$ taken from the $6 \mathrm{~h}$ and $24 \mathrm{~h}$ cultures was centrifuged at $10,000 \times \mathrm{g}$ for $10 \mathrm{~min}$ at $23^{\circ} \mathrm{C}$ and re-suspended in $1 \mathrm{~mL}$ of phosphate saline buffer (PBS; Merk). Each resuspended bacteria sample was separately treated with OLE at $100 \mathrm{mg} / \mathrm{mL}$ TPs, as it is higher than other concentrations demonstrating antibacterial activity as previously tested [45]. In a separate 24-well plate, $900 \mathrm{~mL}$ of treatment solution (composed by OLE dissolved in TBS) with $100 \mathrm{mg} / \mathrm{mL}$ TPs was added to $100 \mu \mathrm{L}$ of bacterial inoculum. The effects of the OLE on the strains were evaluated at different times for a total duration of $24 \mathrm{~h}$ by plate counting $(\mathrm{CFU} / \mathrm{mL})$. The potential synergistic effect of OLE and CAP was evaluated at two relevant time points, $6 \mathrm{~h}$ and $24 \mathrm{~h}$ after application of OLE, CAP or OLE + CAP. The samples to be treated with CAP were exposed soon after OLE addition, for $1 \mathrm{~min}$ using air $(5.0 \mathrm{~L} / \mathrm{min})$ 
at atmospheric pressure and RT. All experiments were carried out in triplicate to ensure statistical significance.

\subsection{Statistical Analysis}

Statistical analysis was performed using SPSS 22.0 software (SPSS Inc., Chicago, IL, USA) by conducting one-way analysis of variance (ANOVA, San Francisco, CA, USA) and the Tukey's honestly significant difference (HSD) post hoc test to determine any statistically significant difference among samples. Significance was set at $p<0.05$.

\section{Conclusions}

In this study, the antimicrobial effects of CAP, OLE and their combination against bacterial pathogens, i.e., E. coli, S. aureus and L. Innocua, was investigated. The combined OLE + CAP treatment had substantial antimicrobial activity against the bacterial species under study at early time points $(6 \mathrm{~h})$, whereas individual CAP and OLE treatments showed comparatively poor effects under the conditions surveyed. At the conclusion of this preliminary study on the combined antimicrobial effect of CAP and OLE, a synergistic effect during the exponential phase was evident, suggesting that the combination of these sustainable approaches could offer an innovative strategy for providing microbiological safety in the biomedical and food industry. We can hypothesize the use of OLE as a coating or polymer blend in food or medical packaging, followed by CAP treatment, to ensure a green and safely decontaminated environment.

Author Contributions: Conceptualization, E.V. and J.G.D.1.O.; methodology, E.V., T.W. and H.E.K.; software, J.G.D.1.O.; validation, S.D., M.S. and E.V.; formal analysis, S.D., M.S. and E.V.; investigation, J.G.D.1.O. and J.G.-M.; resources, T.H. and E.V.; data curation, J.G.D.l.O.; writing-original draft preparation, J.G.D.1.O.; writing-review and editing, J.G.D.1.O., E.V., M.S., S.D., T.W.; visualization, H.E.K. and E.V.; supervision, J.G.-M. and E.V.; project administration, R.D.S., S.D. and E.V.; funding acquisition, E.V. and R.D.S. All authors have read and agreed to the published version of the manuscript.

Funding: This work was supported by the Doctorate Degree Program of the Tuscany Region, Italy. The group has received support from the Department of Chemical and Process Engineering of the University of Surrey, Fourth State Medicine Ltd., the National Biofilm Innovation Centre UK, an Impact Acceleration Grant (IAA-KN9149C) of the University of Surrey, an IAA-EPSRC Grant (RN0281J) and the Royal Society. E.V. is grateful to the Royal Academy of Engineering for an Industrial Fellowship.

Institutional Review Board Statement: Not applicable.

Informed Consent Statement: Not applicable.

Data Availability Statement: Not applicable.

Acknowledgments: Jasmine Esposito-Salsano, Maria Digiacomo and Marco Macchia (University of Pisa) are greatly acknowledged for their technical support to OLE characterization.

Conflicts of Interest: T.W. and T.H. are Research \& Innovation Manager and CTO respectively at Fourth State Medicine Ltd.

Sample Availability: Samples of OLE are available from the authors (J.G.D.1.O.).

\section{References}

1. Guillard, V.; Gaucel, S.; Fornaciari, C.; Angellier-Coussy, H.; Buche, P.; Gontard, N. The next generation of sustainable food packaging to preserve our environment in a circular economy context. Front. Nutr. 2018, 5, 1-13. [CrossRef] [PubMed]

2. Isbary, G.; Shimizu, T.; Li, Y.; Stolz, W.; Tomas, H.M.; Morfill, G.; Zimmermmann, J. Cold atmospheric plasma devices for medical issues. Exp. Rev. Med. Dev. 2013, 10, 367-377. [CrossRef]

3. Ben-Othman, S.; Jõudu, I.; Bhat, R. Bioactives from agri-food wastes: Present insights and future challenges. Molecules 2020, 25, 510. [CrossRef] [PubMed]

4. Al-Hashimi, A.G. Antioxidant and antibacterial activities of Hibiscus sabdariffa L. extracts. Afr. J. Food Sci. 2012, 6, 506-511. [CrossRef] 
5. Amaral, G.P.; Mizdal, C.R.; Stefanello, S.T.; Mendez, A.S.L.; Puntel, R.L.; de Campos, M.M.A.; Soares, F.A.A.; Fachinetto, R. Antibacterial and antioxidant effects of Rosmarinus officinalis L. extract and its fractions. J. Tradit. Complement. Med. 2018, 9, 383-392. [CrossRef]

6. Moemenbellah-Fard, M.D.; Abdollahi, A.; Ghanbariasad, A.; Osanloo, M. Antibacterial and leishmanicidal activities of Syzygium aromaticum essential oil versus its major ingredient, eugenol. Flavour Fragr. J. 2020, 35, 534-540. [CrossRef]

7. Fani, M.; Kohanteb, J. In vitro antimicrobial activity of thymus vulgaris essential oil against major oral pathogens. J. Evidence-Based Complement. Altern. Med. 2017, 22, 660-666. [CrossRef]

8. Ahmed, S.; Moni, B.M.; Ahmed, S.; Gomes, D.J.; Shohael, A.M. Comparative phytochemical, antioxidant, and antibacterial study of different parts of Doigota plants (Bixa orellana L.). Bull. Natl. Res. Cent. 2020, 44, 1-10. [CrossRef]

9. Sharifi-Rad, M.; Nazaruk, J.; Polito, L.; Morais-Braga, M.F.B.; Rocha, J.E.; Coutinho, H.D.M.; Salehi, B.; Tabanelli, G.; Montanari, C.; del Mar Contreras, M.; et al. Matricaria genus as a source of antimicrobial agents: From farm to pharmacy and food applications. Microbiol. Res. 2018, 215, 76-88. [CrossRef] [PubMed]

10. Heck, C.I.; De Mejia, E.G. Yerba mate tea (Ilex paraguariensis): A comprehensive review on chemistry, health implications, and technological considerations. J. Food Sci. 2007, 77, R138-R151. [CrossRef] [PubMed]

11. Razavi, S.M.; Zarrini, G.; Molavi, G.; Ghasemi, G. Bioactivity of Malva sylvestris L., a medicinal plant from Iran. Iran. J. Basic Med. Sci. 2011, 14, 574-579. [PubMed]

12. Fayera, S.; Babu, G.N.; Dekebo, A.; Bogale, Y. Phytochemical investigation and antimicrobial study of leaf extract of Plantago lanceolata. Nat. Prod. Chem. Res. 2018, 6, 1000311. [CrossRef]

13. Kolodziejczyk-Czepas, J.; Liudvytska, O. Rheum rhaponticum and Rheum rhabarbarum: A review of phytochemistry, biological activities and therapeutic potential. Phytochem. Rev. 2020. [CrossRef]

14. Fufa, B.K. Anti-bacterial and anti-fungal properties of garlic extract (Allium sativum): A Review. Microbiol. Res. J. Int. 2019, 28, 1-5. [CrossRef]

15. Seow, Y.X.; Yeo, C.R.; Chung, H.L.; Yuk, H.G. Plant essential oils as active antimicrobial agents. Crit. Rev. Food Sci. Nutr. 2014, 54, 625-644. [CrossRef]

16. Lee, O.-H.; Lee, B.-Y. Antioxidant and antimicrobial activities of individual and combined phenolics in Olea europaea leaf extract. Bioresour. Technol. 2010, 101, 3751-3754. [CrossRef]

17. Salomone, R.; Ioppolo, G. Environmental impacts of olive oil production: A Life Cycle Assessment case study in the province of Messina (Sicily). J. Clean. Prod. 2012, 28, 88-100. [CrossRef]

18. Lafka, T.-I.; Lazou, A.; Sinanoglou, V.; Lazos, E. Phenolic extracts from wild olive leaves and their potential as edible oils antioxidants. Foods 2013, 2, 18-31. [CrossRef]

19. Rombaut, N.; Tixier, A.-S.; Bily, A.; Chemat, F. Green extraction processes of natural products as tools for biorefinery. Biofuels Bioprod. Bioref. 2014, 8, 530-544. [CrossRef]

20. Özcan, M.M.; Matthäus, B. A review: Benefit and bioactive properties of olive (Olea europaea L.) leaves. Eur. Food Res. Technol. 2017, 243, 89-99. [CrossRef]

21. Nediani, C.; Ruzzolini, J.; Romani, A.; Calorini, L. Oleuropein, a bioactive compound from Olea europaea L., as a potential preventive and therapeutic agent in non-communicable diseases. Antioxidants 2019, 8, 578. [CrossRef]

22. Hashmi, M.A.; Khan, A.; Hanif, M.; Farooq, U.; Perveen, S. Traditional uses, phytochemistry, and pharmacology of Olea europaea (Olive). Evidence-Based Complement. Altern. Med. 2015, 2015, 541591. [CrossRef] [PubMed]

23. Şahin, S.; Bilgin, M. Olive tree (Olea europaea L.) leaf as a waste by-product of table olive and olive oil industry: A review. J. Sci. Food Agric. 2018, 98, 1271-1279. [CrossRef] [PubMed]

24. Poudyal, H.; Campbell, F.; Brown, L. Olive leaf extract attenuates cardiac, hepatic, and metabolic changes in high carbohydratehigh fat-fed rats. J. Nutr. 2010, 140, 946-953. [CrossRef] [PubMed]

25. Sudjana, A.N.; D'Orazio, C.; Ryan, V.; Rasool, N.; Ng, J.; Islam, N.; Riley, T.V.; Hammer, K.A. Antimicrobial activity of commercial Olea europaea (olive) leaf extract. Int. J. Antimicrob. Agents 2009, 33, 461-463. [CrossRef] [PubMed]

26. Djenane, D.; Gómez, D.; Yangüela, J.; Roncalés, P.; Ariño, A. Olive leaves extract from Algerian oleaster (Olea europaea var. sylvestris) on microbiological safety and shelf-life stability of raw Halal minced beef during display. Foods 2019, 8, 10. [CrossRef]

27. Albertos, I.; Avena-Bustillos, R.J.; Martín-Diana, A.B.; Du, W.X.; Rico, D.; McHugh, T.H. Antimicrobial Olive Leaf Gelatin films for enhancing the quality of cold-smoked Salmon? Food Packag. Shelf Life 2017, 13, 49-55. [CrossRef]

28. Pereira, A.P.; Ferreira, I.C.F.R.; Marcelino, F.; Valentão, P.; Andrade, P.B.; Eabra, R.; Estevinho, L.; Bento, A.; Pereira, J.A. Phenolic compounds and antimicrobial activity of olive (Olea europaea L. Cv. Cobrançosa) leaves. Molecules 2007, 12, 1153-1162. [CrossRef] [PubMed]

29. Tranter, H.S.; Tassou, S.C.; Nychas, G.J. The effect of the olive phenolic compound, oleuropein, on growth and enterotoxin B production by Staphylococcus aureus. J. Appl. Bacteriol. 1993, 74, 253-259. [CrossRef]

30. Ghomari, O.; Sounni, F.; Massaoudi, Y.; Ghanam, J.; Drissi Kaitouni, L.B.; Merzouki, M.; Benlemlih, M. Phenolic profile (HPLCUV) of olive leaves according to extraction procedure and assessment of antibacterial activity. Biotechnol. Rep. 2019,23, e00347. [CrossRef] [PubMed]

31. Bourke, P.; Ziuzina, D.; Han, L.; Cullen, P.J.; Gilmore, B.F. Microbiological interactions with cold plasma. J. Appl. Microbiol. 2017, 123, 308-324. [CrossRef] [PubMed] 
32. Pan, Y.; Cheng, J.-H.; Sun, D.-W. Cold plasma-mediated treatments for shelf life extension of fresh produce: A review of recent research developments. Compr. Rev. Food Sci. Food Saf. 2019, 18, 1312-1326. [CrossRef] [PubMed]

33. Graves, D. The emerging role of reactive oxygen and nitrogen species in redox biology and some implications for plasma applications to medicine and biology. J. Phys. D Appl. Phys. 2012, 45, 263001. [CrossRef]

34. Djenane, D.; Aboudaou, M.; Djenane, F.; García-Gonzalo, D.; Pagán, R. Improvement of the shelf-life status of modified atmosphere packaged camel meat using nisin and Olea europaea subsp. laperrinei leaf extract. Foods 2020, 9, 1336. [CrossRef] [PubMed]

35. Guo, J.; Huang, K.; Wang, J. Bactericidal effect of various non-thermal plasma agents and the influence of experimental conditions in microbial inactivation: A review. Food Control 2015, 50, 482-490. [CrossRef]

36. Cullen, P.J.; Lalor, J.; Scally, L.; Boehm, D.; Milosavljević, V.; Bourke, P.; Keener, K. Translation of plasma technology from the lab to the food industry. Plasma Process. Polym. 2018, 15, 1-11. [CrossRef]

37. Chang, Y.; Tu, P.; Wu, M.; Hsueh, T.; Hsu, S. A study on chitosan modification of polyester fabrics by atmospheric pressure plasma and its antibacterial effects. Fibers Polym. 2008, 9, 307-311. [CrossRef]

38. Nikiforov, A.; Deng, X.; Xiong, Q.; Cvelbar, U.; Degeyter, N.; Morent, R.; Leys, C. Non-thermal plasma technology for the development of antimicrobial surfaces: A review. J. Phys. D Appl. Phys. 2016, 49, 204002. [CrossRef]

39. Karam, L.; Jama, C.; Mamede, A.-S.; Fahs, A.; Louarn, G.; Dhulster, P.; Chihib, N.-E. Study of nisin adsorption on plasma-treated polymer surfaces for setting up materials with antibacterial properties. Reactive Funct. Polym. 2013, 73, 1473-1479. [CrossRef]

40. Duday, D.; Vreuls, C.; Moreno, M.; Frache, G.; Boscher, N.D.; Zocchi, G.; Archambeau, C.; Van De Weerdt, C.; Martial, J.; Choquet, P. Atmospheric pressure plasma modified surfaces for immobilization of antimicrobial nisin peptides. Surf. Coat. Technol. 2013, 218, 152-161. [CrossRef]

41. Schmid, M.; Dallmann, K.; Bugnicourt, E.; Cordoni, D.; Wild, F.; Lazzeri, A.; Noller, K. Properties of whey-protein-coated films and laminates as novel recyclable food packaging materials with excellent barrier properties. Int. J. Polym. Sci. 2012, 2012, 5-7. [CrossRef]

42. Tihminlioglu, F.; Atik, I.D.; Özen, B. Water vapor and oxygen-barrier performance of corn-zein coated polypropylene films. J. Food Eng. 2010, 96, 342-347. [CrossRef]

43. Laroussi, M.; Leipold, F. Evaluation of the roles of reactive species, heat, and UV radiation in the inactivation of bacterial cells by air plasmas at atmospheric pressure. Int. J. Mass Spectrom. 2004, 233, 81-86. [CrossRef]

44. McKeen, L. Introduction to food irradiation and medical sterilization. In Film Properties of Plastics and Elastomers, 3rd ed.; McKeen, L., Ed.; Elsevier Inc.: Amsterdam, The Netherlands, 2012; pp. 1-40. ISBN 978-1-4557-2551-9.

45. De la Ossa, J.G.; Felice, F.; Azimi, B.; Salsano, J.E.; Digiacomo, M.; Macchia, M.; Danti, S.; Di Stefano, R. Waste autochthonous tuscan olive leaves (Olea europaea var. olivastra seggianese) as antioxidant source for biomedicine. Int. J. Mol. Sci. 2019, 20, 5918. [CrossRef]

46. Liu, Y.; McKeever, L.C.; Malik, N.S.A. Assessment of the antimicrobial activity of olive leaf extract against foodborne bacterial pathogens. Front. Microbiol. 2017, 8, 1-8. [CrossRef] [PubMed]

47. Costello, K.M.; Gutierrez-Merino, J.; Bussemaker, M.; Ramaioli, M.; Baka, M.; Van Impe, J.F.; Velliou, E.G. Modelling the microbial dynamics and antimicrobial resistance development of Listeria in viscoelastic food model systems of various structural complexities. Int. J. Food Microbiol. 2018, 286, 15-30. [CrossRef]

48. Costello, K.M.; Gutierrez-Merino, J.; Bussemaker, M.; Smet, C.; Van Impe, J.F.; Velliou, E.G. A multi-scale analysis of the effect of complex viscoelastic models on Listeria dynamics and adaptation in co-culture systems. AIChE J. 2020, 66, 1-15. [CrossRef]

49. Zhou, J.; Velliou, E.; Hong, S.H. Investigating the effects of nisin and free fatty acid combined treatment on Listeria monocytogenes inactivation. LWT-Food Sci. Technol. 2020, 133, 110115. [CrossRef]

50. Difonzo, G.; Russo, A.; Trani, A.; Paradiso, V.M.; Ranieri, M.; Pasqualone, A.; Summo, C.; Tamma, G.; Silletti, R.; Caponio, F. Green extracts from Coratina olive cultivar leaves: Antioxidant characterization and biological activity. J. Funct. Foods 2017, 31, 63-70. [CrossRef]

51. Mai-Prochnow, A.; Clauson, M.; Hong, J.; Murphy, A.B. Gram positive and Gram negative bacteria differ in their sensitivity to cold plasma. Sci. Rep. 2016, 6, 1-11. [CrossRef] [PubMed]

52. Han, L.; Boehm, D.; Patil, S.; Cullen, P.J.; Bourke, P. Assessing stress responses to atmospheric cold plasma exposure using Escherichia coli knock-out mutants. J. Appl. Microbiol. 2016, 121, 352-363. [CrossRef]

53. Dobrynin, D.; Fridman, G.; Friedman, G.; Fridman, A. Physical and biological mechanisms of direct plasma interaction with living tissue. New J. Phys. 2009, 11, 115020. [CrossRef]

54. Surowsky, B.; Fröhling, A.; Gottschalk, N.; Schlüter, O.; Knorr, D. Impact of cold plasma on Citrobacter freundii in apple juice: Inactivation kinetics and mechanisms. Int. J. Food Microbiol. 2014, 174, 63-71. [CrossRef]

55. Yang, D.C.; Blair, K.M.; Salama, N.R. Staying in shape: The impact of cell shape on bacterial survival in diverse environments. Microbiol. Mol. Biol. Rev. 2016, 80, 187-203. [CrossRef] [PubMed]

56. von Woedtke, T.; Metelmann, H.-R.; Weltmann, K.-D. Clinical plasma medicine: State and perspectives of in vivo application of cold atmospheric plasma. Contrib. Plasma Phys. 2014, 54, 104-117. [CrossRef]

57. Stoffels, E.; Kieft, I.E.; Sladek, R.E.J.; Van Den Bedem, L.J.M.; Van Der Laan, E.P.; Steinbuch, M. Plasma needle for in vivo medical treatment: Recent developments and perspectives. Plasma Sources Sci. Technol. 2006, 15, S169-S180. [CrossRef] 
58. Yusupov, M.; Bogaerts, A.; Huygh, S.; Snoeckx, R.; Van Duin, A.C.T.; Neyts, E.C. Plasma-induced destruction of bacterial cell wall components: A reactive molecular dynamics simulation. J. Phys. Chem. C 2013, 117, 5993-5998. [CrossRef]

59. Costello, K.M.; Smet, C.; Gutierrez-Merino, J.; Bussemaker, M.; Van Impe, J.F.; Velliou, E.G. The impact of food model system structure on the inactivation of Listeria innocua by cold atmospheric plasma and nisin combined treatments. Int. J. Food Microbiol. 2021, 337, 108948. [CrossRef]

60. Milazzo, M.; Gallone, G.; Marcello, E.; Mariniello, M.D.; Bruschini, L.; Roy, I.; Danti, S. Biodegradable polymeric micro/nanostructures with intrinsic antifouling/antimicrobial properties: Relevance in damaged skin and other biomedical applications. J. Funct. Biomater. 2020, 11, 60. [CrossRef]

61. Danti, S.; Azimi, B.; Candito, M.; Fusco, A.; Sorayani Bafqi, M.S.; Ricci, C.; Milazzo, M.; Cristallini, C.; Latifi, M.; Donnarumma, G.; et al. Lithium niobate nanoparticles as biofunctional interface material for inner ear devices. Biointerphases 2020, 15, 31004. [CrossRef]

62. Romano, L.; Portone, L.; Coltelli, M.B.; Patti, F.; Saija, R.; Iatì, M.A.; Gallone, G.; Lazzeri, A.; Danti, S.; Marago, O.; et al. Intelligent non-colorimetric indicators for the perishable supply chain by non-wovens with photo-programmed thermal response. Nat. Commun. 2020, 11, 5991. [CrossRef] [PubMed] 